\title{
Detection of genetically modified food in digesta and organs of rats fed transgenic potato
}

\author{
A. Sattarzadeh ${ }^{1,2}$, H. Rahnama ${ }^{1,3}$, M. Nikmard ${ }^{1}$ and B. Ghareyazie ${ }^{1}$ \\ ${ }^{1}$ Agricultural Biotechnology Research Institute of Iran (ABRII), \\ Agricultural Research Education and Extension Organization (AREEO), Plant Genetic Engineering and Biosafety Department, \\ P.O. Box 31535-1897, Karaj, Iran \\ ${ }^{2}$ Islamic Azad University, Department of Agricultural Biotechnology, Science and Research Branch, 1584743311 Tehran, Iran
}

KEY WORDS: rat, transgenics, potato, cry1Ab, nptll, detection

Received: $\quad 21$ May 2017

Revised: 26 September 2017

Accepted: 28 May 2018
${ }^{3}$ Corresponding author:

e-mail: hrahnama@abrii.ac.ir

\begin{abstract}
Transgenic potato plants harbouring cry $1 A b$ gene, resistant to potato tuber moth, were used to examine the persistence of recombinant DNA and proteins in the digesta, gastrointestinal tract (GIT) tissues and visceral organs of rats in a 90-day feeding trial. Native plant DNA (chloroplastic gene, $c p$ ) and fragments of cry $1 \mathrm{Ab}$, nptll and nos promoter were tracked in rat organs and tissues by polymerase chain reaction (PCR). Although complete sequences (1200 bp) of cry $1 \mathrm{Ab}$ gene and its decreased size (400 bp) were detected in the rat diets, the presence of these sequences was not confirmed by PCR analysis in the GIT contents of rats fed diets containing transgenic potato. Moreover, the $400 \mathrm{bp}$ sequence of the nptll gene and $300 \mathrm{bp}$ of the nos promoter were detected in the caecum, stomach and rectum contents of some rats fed transgenic potato; however, these sequences were not detected in all rats. Immunoassay showed that Cry $1 \mathrm{Ab}$ protein is detectable in the GIT contents of rats fed transgenic potato, but quantitative assay by ELISA confirmed that the Cry $1 \mathrm{Ab}$ protein was partially degraded (80.3-83.7\% digestibility) after passing through the GIT. Similarly, ELISA assay of NPTII showed that the protein can be digested (76.8-84.36\% digestibility) in the GIT. So, although ingested native and recombinant DNA and protein did not totally degrade in the GIT, it can be indicated that there is no need for concern about the effects of recombinant $c r y 1 A b$ and nptll genes and their products on animals and humans.
\end{abstract}

\section{Introduction}

Consumers have many difficulties in avoiding genetically modified (GM) products due to the ubiquitous presence of GM crops produced worldwide (Buzoianu et al., 2012). Although regulatory agencies issued precise frameworks for adoption of transgenic crops, concerns about the safety of transgenic products still remain (Walsh et al., 2011). Among the most discussable aspects of transgenic crops are toxicity and allergencity (Dona and
Arvanitoyannis, 2009). However, the risk of horizontal transfer of transgens from such products is also raised (Świątkiewicz et al., 2011). The probability of horizontal transfer of antibiotic resistance genes used in the process of producing transgenic crops can induce antibiotic resistance in the human/ animal gastrointestinal tract (GIT) microbiota and soil microflora (Nielsen et al., 1998; Kosieradzka et al., 2010). Therefore, the evaluation of potential risk related to consumption of recombinant protein and DNA is a substantial part of studies on the 
safety of GM crops used in human and animal diets (Kosieradzka et al., 2010; Swiatkiewicz et al., 2014).

The analysis of adverse effects of recombinant DNA absorption from transgenic foods requires intact and stable transgenic DNA sequences passing through human/animals GIT. It appears that the low $\mathrm{pH}$ in the stomach, and nucleases produced in the saliva and small intestine can inactivate and degrade most ingested plant DNA and proteins (Duggan et al., 2000). Sometimes, however, small DNA fragments when bound to soil minerals or proteins can be absorbed in the GIT (Gallori et al., 1994). This process could protect them from degradation (El-Sanhoty et al., 2006).

The passage of food and feed DNA through the GIT barrier is natural; endogenous plant genes were detected in animal tissues and products (Reuter and Aulrich, 2003; Tudisco et al., 2006). The fate of recombinant feed and food DNA in the GIT of animals and its potential absorption and transfer to other tissues was reported by many researchers. The digestive fate of recombinant DNA and protein from transgenic plants has been studied in rats, fish, cattle, sheep, poultry and pigs (El-Sanhoty et al., 2006; Sharma et al., 2006; Walsh et al., 2011; Swiatkiewicz et al., 2014). In the studies using transgenic crops (maize, rice, potato, soyabean) no adverse effects on the nutrition of rats, chickens, broiler chickens, catfish, dairy cattle, bulls and sheep have been shown (Duggan et al., 2003; He et al., 2009; Snell et al., 2012). Nevertheless, the possible survival of recombinant plant DNA fragments in the GIT has been reported, possible hazardous effects and the biological relevance of this data has not yet been substantiated (Mazza et al., 2005; Sharma et al., 2006).

Transgenic potato plants harbouring $c r y l A b$ gene for potato tuber moth (Phthorimaea operculella (Zeller)) resistance have been developed in the Agricultural Biotechnology Research Institute of Iran (Ghasimi Hagh et al., 2009). After field trials, the possible use of this transgenic potato as food and feed will be reported. Although targeted expression of $c r y l A b$ gene, using a light-inducible phosphoenolpyruvate carboxylase (PEPC) promoter, may alleviate biosafety concerns (e.g., Cry1 Ab expression in non-edible parts), fears about the possible adverse effects of the genes and recombinant protein still remain (Świątkiewicz et al., 2011; Swiatkiewicz et al., 2014; Koch et al., 2015).

So, the objective of the present study was to determine the fate of recombinant DNA and proteins in the GIT and verify its possible transfer to tissues and organs of rats fed transgenic potatoes in a 90-day feeding study.

\section{Material and methods}

\section{Potato tuber samples}

The transgenic Bacillus thuringiensis $(\mathrm{Bt})$ potato (Marfona line B8) and its near isogenic non-transgenic parental line (as the control) were grown under greenhouse conditions at the Agricultural Biotechnology Research Institute of Central Iran in Isfahan in 2010. The plants were grown and harvested under the same conditions. The transgenic line was generated using Agrobacteium tumefaciens AGL01 harbouring the binary vector pBPEPCryl Ab (Ghasimi Hagh et al., 2010). The binary vector includes a gene cassette consisting of PEPC promoter, cryl Ab gene and nos terminator (Figure 1). A kanamycin resistance gene (nptII) was used in the cassette as a selectable marker gene. The authenticity of transgenic and nontransgenic potato lines was confirmed by polymerase chain reaction (PCR) analysis.

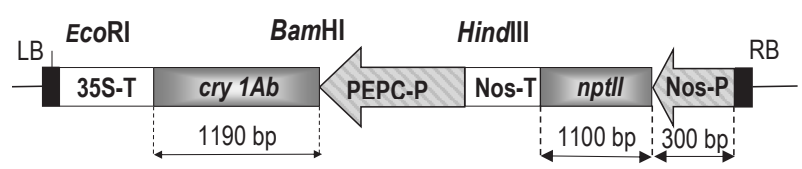

Figure 1. pBPEP-Cry1 $\mathrm{Ab}$ vector used to generate transgenic potato plants

$\mathrm{RB}$ - right border; LB - left border; nptll - neomycin phosphotransferase II gene; Nos-P - neopalin synthase gene promoter; Nos-T - neopalin synthase gene terminator; PEPC-P - phosphoenolpyruvate carboxylase promoter; cry1Ab - structural gene; EcoRI, BamHI and Hindlll - restriction enzymes

After harvesting, the transgenic and non-transgenic potato tubers were divided in two groups. One group was kept under light $\left(60 \mu \mathrm{mol} \cdot \mathrm{m}^{-2} \cdot \mathrm{s}^{-1}\right)$ for 7 days. The other was kept in the dark at $25^{\circ} \mathrm{C}$ for 7 days. The light was used in order to allow the expression of Cry1 $\mathrm{Ab}$ protein in the transgenic potato tubers and therefore study the fate of Cry $1 \mathrm{Ab}$ protein in the GIT of the examined rats. The potato tubers were sliced and dried by incubation at $45^{\circ} \mathrm{C}$. The dried potato chips were ground in a grinder and the powder was used in experimental diets.

\section{Animals, diet and feeding trials}

The experimental protocols were approved by Biosafety and Bioethics Committee in Agricultural Biotechnology Research Institute of Iran (ABRII). In total, 16 adult male and 16 adult female Wistar rats $(130-180 \mathrm{~g})$ were used in the study. Animals purchased from Razi Institute (Karaj, Iran) were grouped randomly into 16 standard cages with two males or two females in each cage. All animals were 
Table 1. Composition of experimental diets: potato powder (\%) added to the basic diet (NRC, 1995) in four groups

\begin{tabular}{lllll}
\hline \multirow{2}{*}{ Compound } & \multicolumn{3}{l}{ Groups } \\
\cline { 2 - 5 } & 1 & 2 & 3 & 4 \\
\hline Dark-treated non-transgenic potato (DN) flour & - & - & - & 20 \\
Light-treated non-transgenic potato (LN) flour & - & - & 20 & \\
Dark-treated transgenic potato (DT) flour & - & 20 & - & - \\
Light-treated transgenic potato (LT) flour & 20 & - & - & - \\
\hline
\end{tabular}

kept under normal healthy conditions $\left(23 \pm 2{ }^{\circ} \mathrm{C}\right.$, $12 \mathrm{~h}$ light/dark cycle, $50-60 \%$ humidity) and fed a basal diet for 1 week. The basal and experimental diets were formulated according to National Research Council (NRC) guidelines (NRC, 1995). The basic diet contained, \%: wheat flour 15, barley flour 8 , maize flour 16.5 , wheat bran 2 , soyabean meal 13, alfalfa meal 2, $\mathrm{NaCl} 0.8$, multivitamin 0.1 , vitamin $\mathrm{E} 0.7$, vitamin $\mathrm{D}_{3} 0.2$, vitamin $\mathrm{C} 0.2$, milk powder 2.5 , meat meal 17 and soya oil 2 . In the experimental diets, $20 \%$ potato flour replaced an equivalent amount of maize-starch (Table 1). Each diet was assessed by PCR analysis to confirm the absence or presence of the crylAb, nptII and nos transgenes.

During feeding treatments, the cages were divided into four groups, each containing two cages with male (M) and two cages with female (F) rats. Animals were fed diet containing light-treated transgenic potato (LT; group 1), dark-treated transgenic potato (DT; group 2), light-treated non-transgenic potato (LN; group 3), and dark-treated non-transgenic potato (DN; group 4). All rats had ad libitum access to feed and water for 90 days. The animals were observed and monitored daily for signs of possible toxicity resulting from feed and water consumption.

\section{Tissue collection}

At the end of 90-day feeding trial, the rats were euthanized and blood samples were collected into polypropylene tubes containing ethylenediaminetetraacetic acid (EDTA) and then stored at $-70{ }^{\circ} \mathrm{C}$ for further analysis. The rat carcasses were opened under sterile conditions. The gut was carefully dissected and laid out on a flat surface. The digesta from each section (stomach, caecum and rectum) were carefully removed, collected in $1.5 \mathrm{ml}$ tubes and stored at $-70{ }^{\circ} \mathrm{C}$ to await DNA and protein analysis. Small samples of the brain, liver, kidney, spleen, heart, testes, stomach, duodenum, jejunum, ileum, caecum, rectum and blood were collected and stored like digesta samples. The digesta samples from each GIT segment and organ from all animals in each group were pooled prior to DNA analysis.

\section{DNA extraction and PCR analysis}

DNA extraction. A Magnan Blood DNA Extraction Kit (Gil NanoGene Biotech, Tehran, Iran) for DNA extraction from blood was used according to manufacturer's instructions. A Magnan Plant DNA Extraction Kit (Gil NanoGene Biotech, Tehran, Iran) was used to extract the DNA from the potato tubers and diets given to rats. A QIAamp DNA Stool Mini-Kit (\#51504, Qiagen, Hilden, Germany) and a DNeasy Blood and Tissue Kit (\#69506, Qiagen, Hilden, Germany) were used for DNA extraction from digesta and all other tissue samples, respectively.

The concentration of isolated DNA was measured using a Nanodrop (Hoefer, San Francisco, CA, USA) according to manufacturer's instructions. The quality of the extracted nucleic acid was controlled using agarose gel electrophoresis. The DNA concentration was adjusted to $25-30 \mathrm{ng} \cdot \mu \mathrm{l}^{-1}$ for PCR analysis.

Oligonucleotide primers. Two pairs of oligonucleotide primers were used to detect intrinsic control gene, one for potato ( $c p$, gene encoding chloroplastic gene; primers Pot-cp, product length $111 \mathrm{bp}$ ) and the second one for rat (Mstn, gene encoding myostatin; primers Mstn, product length $97 \mathrm{bp}$ ) (El-Sanhoty et al., 2006). The next four pairs of primers were used to detect the recombinant genes: crylAb, nos and nptII (Table 2). The NptII and Nos primers were designed to amplify recombinant $n p t I I$ and nos promoter sequences, respectively. Cry400 and Cry1200 primers, respectively, were designed to amplify a short (400 bp) and a long (1200 bp) sequence of synthetic crylAb gene B. thuringiensis subsp. Kurstaki used in production of transgenic potato plants. All primers were synthesized by Metabion International AG (Martinsried, Germany)

Table 2. Primer pairs used for polymerase chain reaction (PCR)

\begin{tabular}{llc}
\hline Primer & Sequence of primer & $\begin{array}{l}\text { Length of PCR } \\
\text { product, bp }\end{array}$ \\
\hline $\begin{array}{l}\text { Pot-cp-F } \\
\text { Pot-cp-R }\end{array}$ & $\begin{array}{l}\text { 5'-ctctttacatcgaaacttcagaaag-3' } \\
\text { 5'-aaactacggattcgggtcg-3' }\end{array}$ & 111 \\
Nptll-F & 5'-gctattcggctatgactgggcac-3' & 400 \\
Nptll-R & 5'-tcatcctgatcgacaagaccggc-3' & \\
Mstn-F & 5'-ttgtgcaaatcctgagactcat-3' & 97 \\
Mstn-R & 5'-ataccagtgcctgggttcat-3' & \\
NosP-F & 5'-tcatgagcggagaattaagggag-3' & 300 \\
NosP-R & 5'-aggtgcagattatttggattgagagtg-3' & \\
Cry400-F & 5'-ggacatcctgaacagcatcacc-3' & 400 \\
Cry400-R & 5'-ggcctgcacgtacacgctcag-3' & \\
Cry1200-F & 5'-atcgagaccggctacaccc-3' & 1200 \\
Cry1200-R & 5'-gaggtggcacgttgttgttc-3' & \\
\hline
\end{tabular}


and obtained in a lyophilized state. The primers were dissolved in sterile distilled water to obtain a final concentration of $20 \mathrm{pmol} \cdot \mathrm{ml}^{-1}$.

PCR conditions. PCR reactions were performed using $25 \mathrm{ng}$ of template DNA in $25 \mu \mathrm{l}$ of $50 \mathrm{mM}$ $\mathrm{KCl}, 10 \mathrm{mM}$ Tris- $\mathrm{HCl}$ (pH 8.3), $1.5 \mathrm{mM} \mathrm{MgCl}$, $200 \mu \mathrm{M}$ dNTPs, $50 \mathrm{pM}$ of each primer and $1 \mathrm{U}$ Taq DNA polymerase (Roche, Mannheim, Germany). Amplification was carried out in a thermocycler (Techne, Staffordshire, UK) under thermal and cyclic conditions (Table 3 ). The PCR products were separated by electrophoresis onto $1 \%(\mathrm{w} / \mathrm{v})$ agarose gel followed by a post staining step with Gelred where visualized under UV light. Samples with positive results at least in two replicates were considered positive (Chowdhury et al., 2003).

Table 3. Cycling conditions for amplifying polymerase chain reaction (PCR) products

\begin{tabular}{|c|c|c|c|c|c|c|}
\hline Primer & $\begin{array}{l}\text { Initial } \\
\text { activation }\end{array}$ & $\begin{array}{l}\text { Denatur- } \\
\text { ation }\end{array}$ & $\begin{array}{l}\text { Anneal- } \\
\text { ing }\end{array}$ & $\begin{array}{l}\text { Exten- } \\
\text { sion }\end{array}$ & Cycles & $\begin{array}{l}\text { Final } \\
\text { elongation }\end{array}$ \\
\hline Pot-cp & $\begin{array}{l}4 \text { min at } \\
94{ }^{\circ} \mathrm{C}\end{array}$ & $\begin{array}{l}30 \mathrm{~s} \text { at } \\
94^{\circ} \mathrm{C}\end{array}$ & $\begin{array}{l}30 \mathrm{~s} \text { at } \\
60^{\circ} \mathrm{C}\end{array}$ & $\begin{array}{l}30 \mathrm{~s} \text { at } \\
72^{\circ} \mathrm{C}\end{array}$ & 36 & $\begin{array}{l}5 \text { min at } \\
72^{\circ} \mathrm{C}\end{array}$ \\
\hline Nptll & $\begin{array}{l}5 \text { min at } \\
94^{\circ} \mathrm{C}\end{array}$ & $\begin{array}{l}30 \mathrm{~s} \text { at } \\
94^{\circ} \mathrm{C}\end{array}$ & $\begin{array}{l}30 \mathrm{~s} \text { at } \\
60^{\circ} \mathrm{C}\end{array}$ & $\begin{array}{l}30 \mathrm{~s} \text { at } \\
72^{\circ} \mathrm{C}\end{array}$ & 36 & $\begin{array}{l}5 \text { min at } \\
72{ }^{\circ} \mathrm{C}\end{array}$ \\
\hline Mstn & $\begin{array}{l}5 \text { min at } \\
94{ }^{\circ} \mathrm{C}\end{array}$ & $\begin{array}{l}30 \mathrm{~s} \text { at } \\
94^{\circ} \mathrm{C}\end{array}$ & $\begin{array}{l}30 \mathrm{~s} \text { at } \\
60^{\circ} \mathrm{C}\end{array}$ & $\begin{array}{l}30 \mathrm{~s} \text { at } \\
72^{\circ} \mathrm{C}\end{array}$ & 36 & $\begin{array}{l}5 \text { min at } \\
72{ }^{\circ} \mathrm{C}\end{array}$ \\
\hline NosP & $\begin{array}{l}4 \text { min at } \\
94{ }^{\circ} \mathrm{C}\end{array}$ & $\begin{array}{l}30 \mathrm{~s} \text { at } \\
94{ }^{\circ} \mathrm{C}\end{array}$ & $\begin{array}{l}30 \mathrm{~s} \text { at } \\
60{ }^{\circ} \mathrm{C}\end{array}$ & $\begin{array}{l}30 \mathrm{~s} \text { at } \\
72^{\circ} \mathrm{C}\end{array}$ & 36 & $\begin{array}{l}5 \text { min at } \\
72{ }^{\circ} \mathrm{C}\end{array}$ \\
\hline Cry1200 & $\begin{array}{l}5 \text { min at } \\
94^{\circ} \mathrm{C}\end{array}$ & $\begin{array}{l}60 \mathrm{~s} \text { at } \\
94{ }^{\circ} \mathrm{C}\end{array}$ & $\begin{array}{l}60 \mathrm{~s} \text { at } \\
58{ }^{\circ} \mathrm{C}\end{array}$ & $\begin{array}{l}90 \mathrm{~s} \text { at } \\
72{ }^{\circ} \mathrm{C}\end{array}$ & 36 & $\begin{array}{l}5 \text { min at } \\
72^{\circ} \mathrm{C}\end{array}$ \\
\hline Cry400 & $\begin{array}{l}4 \text { min at } \\
94^{\circ} \mathrm{C}\end{array}$ & $\begin{array}{l}30 \mathrm{~s} \text { at } \\
94{ }^{\circ} \mathrm{C}\end{array}$ & $\begin{array}{l}30 \mathrm{~s} \text { at } \\
60^{\circ} \mathrm{C}\end{array}$ & $\begin{array}{l}30 \mathrm{~s} \text { at } \\
72^{\circ} \mathrm{C}\end{array}$ & 36 & $\begin{array}{l}5 \text { min at } \\
72^{\circ} \mathrm{C}\end{array}$ \\
\hline
\end{tabular}

\section{Cry1Ab and NptII protein detection}

Lateral flow strip method. A lateral flow test strips (Bt-Cry1 Ab/1 Ac Immuno-Strip; Agdia, Elkhart, IN, USA) were used according to manufacturer's instructions to assay the presence of Cry1 $\mathrm{Ab}$ protein in potato tubers, rat diet, GIT contents and tissues. Protein was extracted from $500 \mathrm{mg}$ samples using sample extraction buffer 4 (SEB4). The solid material was allowed to settle in the tubes for 1-2 min and then the test strips were inserted into the tubes and left until the control line developed.

Enzyme-linked immunosorbent assay. Determination of the Cry1 Ab and NptII proteins was carried out using a commercially available enzyme-linked immunosorbentassay (ELISA) kits according to manufacturer's instructions (Bt-Cry1Ab/1 Ac ELISA; complete kit PSP 06200/0288 and nptII ELISA: complete kit PSP 73000/0288; Agdia; Elkhart, IN, USA). The samples were ground under liquid nitrogen using a mortar and a pestle. Total protein was extracted from the ground samples using phosphate buffer saline (PBS: $137 \mathrm{mM} \mathrm{NaCl}, 2.7 \mathrm{mM} \mathrm{KCl}, 10 \mathrm{mM}$ $\mathrm{Na}_{2} \mathrm{HPO}_{4}, 2 \mathrm{mM} \mathrm{KH}_{2} \mathrm{PO}_{4}, 0.08 \%$ Tween 20, $\mathrm{pH} 7.4$ ). The control Cry $1 \mathrm{Ab}$ and NPTII proteins were diluted and used in the following concentrations to create a standard curve: $0,0.5,1.0,1.5$ and $2 \mathrm{ng} \cdot \mathrm{ml}^{-1}$.

The ELISA plate was loaded with $100 \mu \mathrm{l}$ of extracted protein, standard protein or control samples and incubated for $2 \mathrm{~h}$ at room temperature. After washing with PBS buffer, $100 \mu l$ of antibody enzyme conjugate was added to each well and then incubated for $2 \mathrm{~h}$. The plates were washed using PBS buffer and then $100 \mu \mathrm{l}$ of 3,3',5,5'-tetramethylbenzidine (TMB; provided by kit supplier) was added and incubated for $20 \mathrm{~min}$ at room temperature. Plates were read at $650 \mathrm{~nm}$ in an ELISA reader (Thermo-Max; Molecular Devices, Sunnyvale, CA, USA). The amount of Cry1 Ab and NPTII proteins was expressed as ng of Cry1 Ab or NPTII protein per g of wet sample. Each sample was assayed in triplicate.

\section{Statistical analysis}

All statistical analyses were performed using SAS version 9.1 (SAS Institute Inc., Cary, NC, USA). The significance of differences has been tested using the parametric analysis of variance (ANOVA). The differences were considered significant at $P \leq 0.05$.

\section{Results}

\section{Rat performance}

The animals from all groups were in good health throughout the study. There were no significant differences in general health and growth rate of the rats between groups (data not shown).

\section{Potato tubers and diets}

PCR analysis using specific primer pairs for crylAb, nptII and nos sequences confirmed the authenticity of transgenic and non-transgenic potato tubers and diets (Figure 2). This analysis also identified nos, nptII and cryl $1 \mathrm{Ab}$ genes in all diets containing transgenic potato tubers.

\section{Detection of recombinant DNA in GIT contents}

In all experiments, the quality of each DNA sample extracted from the diet and GIT contents was first verified using $c p$ gene. The primer pairs detected potato DNA fragments in the GIT contents of rats fed transgenic and non-transgenic potatoes (Figure 3A). The quality of the DNA 


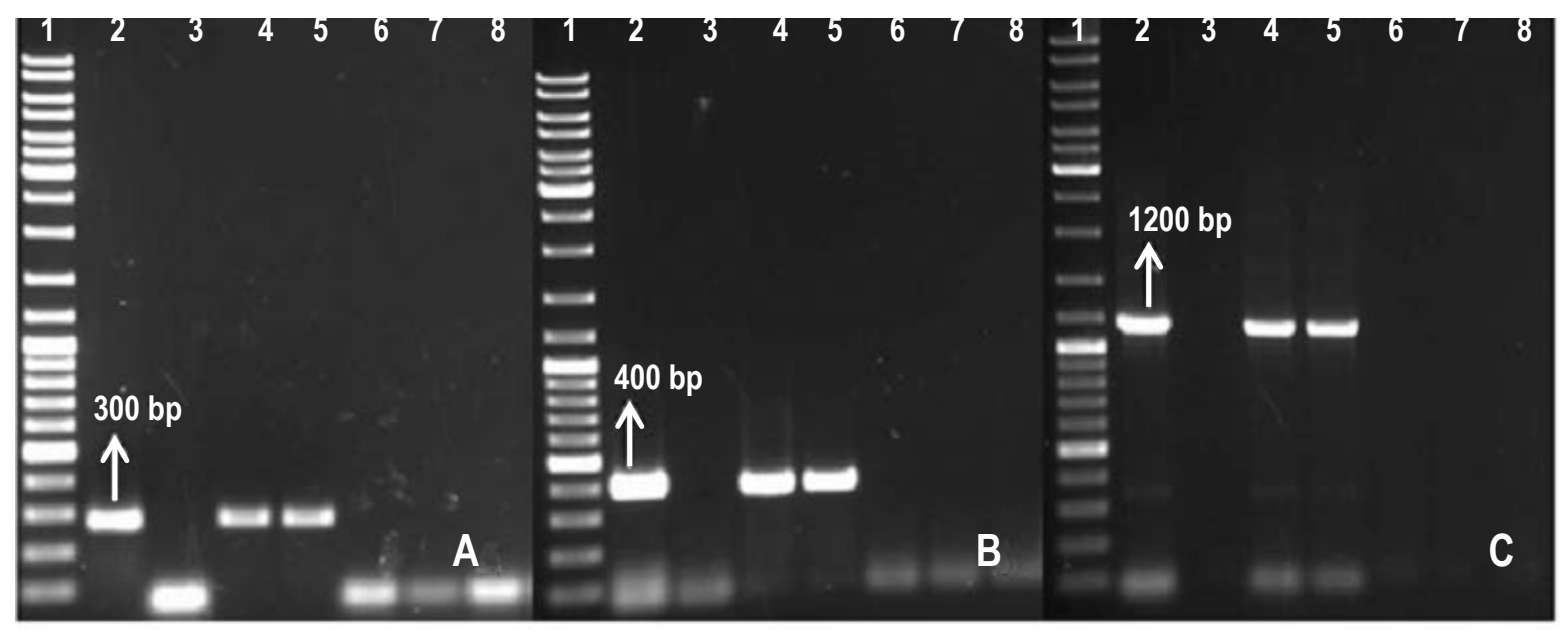

Figure 2. Confirmation of transgenic and non-transgenic potato tubers and diets by PCR analysis using NosP (A), Nptll (B) and Cry1200 (C) primers (see Table 2)

Lines: (1) ladder (GeneRuler, \#SM0333, Fermentas, Waltham, MA, USA); (2) pPEP-Cry1Ab plasmid (positive control); (3) water (negative control); (4) diet containing LT potato; (5) diet containing DT potato; (6) diets free of potato (control diet); (7) diet containing LN potato; (8) diet containing DN potato; $\mathrm{T}$ - transgenic; $\mathrm{N}$ - non-transgenic; $\mathrm{L}$ - light-treated; $\mathrm{D}$ - dark-treated

extracted from rat organs was verified by PCR using the Mstn primer pairs to amplify a segment of the mammalian and avian gene encoding myostatin (El-Sanhoty et al., 2006). The results showed that the DNA extracted from the diets and samples collected from different sections of the GIT and organs of rats had sufficient quality for detection of DNA fragments in PCR analysis (Figure 3B).

The stomach, caecal and rectal contents were positive for the $c p$ gene in $>95 \%$ of rats fed transgenic and non-transgenic potatoes (data not shown).

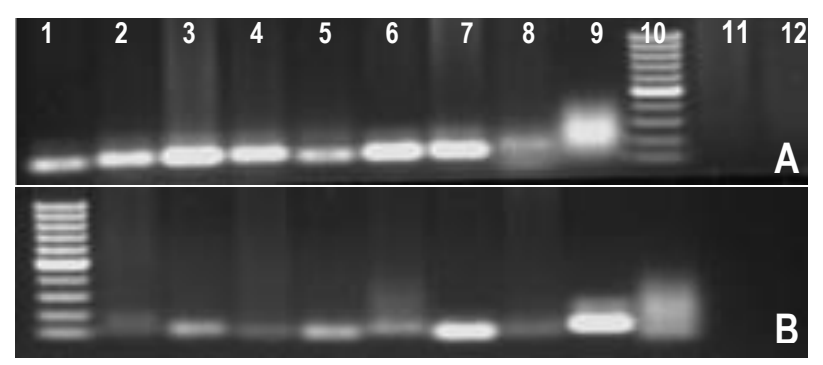

Figure 3. PCR analysis for verification of extracted DNA by (A) Pot-cp primers in diets and digesta from: (1) M-NT stomach; (2) F-LT caecum; (3) diet containing DT potato; (4) M-LT jejunum; (5) M-LT ileum; (6) diet containing DN potato; (7) diet containing LT potato; (8) F-DT rectum; (9) F-LT duodenum; (10) ladder (GeneRuler \#SM0333, Fermentas, Waltham, MA, USA); (11) water (negative control); (12) stomach tissue (negative control); and (B) Mstn primers in rat organs: (1) ladder (GeneRuler \#SM0333, Fermentas, Waltham, MA, USA); (2) M-LN testes; (3) F-LT liver; (4) M-DN rectum; (5) F-LN caecum; (6) F-LT spleen; (7) M- LN lung; (8) F-DT rectum; (9) F-DN stomach; (10) M-DT kidney; (11) rectum content (negative control); (12) water (negative control); $\mathrm{F}$ - female; $\mathrm{M}$ - male; $\mathrm{T}$ - transgenic; $\mathrm{N}$ - non-transgenic; $\mathrm{L}$ - lighttreated; $\mathrm{D}$ - dark-treated
Although, PCR analysis confirmed the presence of $c r y l A b$ gene in rat diets, it did not show positive results for Cry 1200 or Cry 400 primer pairs in any sample of GIT contents. The results indicated that $c r y l A b$ gene sequences had degraded into small segments by digestion in the GIT (Figure 4A; Table 3).

PCR analysis of GIT contents using NptII primers confirmed the presence of nptII gene segments in the caecal contents of M-DT rats. The nptII gene was also detected in the stomach of F-DT and M-LT rats. PCR analysis of rectal contents for the nptII gene was positive for F-DT rats (Figure 4B, Table 4). None of the control rats exhibited positive results for the NptII primer pairs.

The nos sequence was detected in the cecal contents of F-LT and M-LT rats and in the rectal contents of F-DT and M-LT rats. PCR analysis confirmed the presence of nos sequences in the stomach contents of F-DT and F-LT rats. No nos promoter sequence was detected in the control rats (Figure 4C; Table 4).

\section{Detection of recombinant DNA in rat organs and tissues}

The Mstn gene (as internal control) was detected by PCR analysis in all rat tissues (Figure 3B). The results confirmed the successful extraction of DNA from rat tissues and their amplification by PCR. The same tissues were assayed for the presence of crylAb, nos and nptII genes using PCR analysis. The results showed no amplification for the tested samples; however, $c p$ gene segments were detected in 


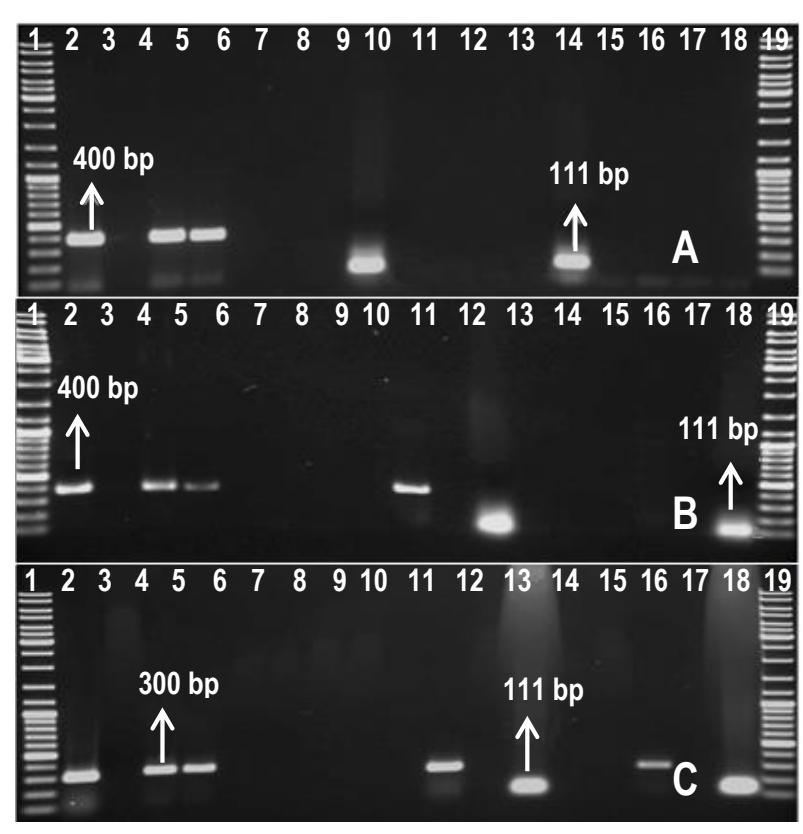

Figure 4. Detection of (A) cry1Ab, (B) nptll and (C) nos genes in rectum contents

Lines: (1), (19) ladder (GeneRuler \#SM0333, Fermentas, Waltham, MA, USA) (2) pBPE-Cry1Ab plasmid (positive control); (3) water (negative control); (4) DT diet; (5) LT diet; (6) control diet (no potato); (7) LN diet; (8) DN diet; (9A), (14A), (12B), (18B), (13C), (18C): positive control (cp gene expression); (10A), (10B), (11C): F-DT; (11A), (16B), (16C): M-LT; (12A), (9B), (9C),: M-DT; (13A), (11B), (10C): F-LT; (15A), (13B), (12C): F-DN; (16A), (14B), (14C): M-LN; (17A), (15B), (15C): M-DN; (18A), (17B), (17C): F-LN; $\mathrm{F}$ - female; $\mathrm{M}$ - male; $\mathrm{T}$ - transgenic; $\mathrm{N}$ - non-transgenic; $\mathrm{L}$ - light-treated; $\mathrm{D}$ - dark-treated

two out of three replications in the duodenum tissue of rats fed transgenic potato (data not shown). This could be attributed to pollution of the sample with the contents of the duodenum.

\section{Detection of Cry1Ab protein}

Immunochromatographic strip assay for detection of $\mathrm{Cry} 1 \mathrm{Ab}$ protein was positive in the diets containing light-treated transgenic potato (Figure 5). Immunoassay detected Cryl $\mathrm{Ab}$ protein in the stomach, caecum and rectum contents of rats fed transgenic potato (Table 5). Diets containing DT or non-transgenic potato and all GIT tissues and other organs in rats fed non-transgenic or DT potato showed no positive reaction to immune strip tests.

The amounts of Cry $1 \mathrm{Ab}$ protein detected by ELISA were: in the LT diet $-49.3 \mathrm{ng} \cdot \mathrm{g}^{-1}$ (fresh weight), and in the rectal contents of $\mathrm{M}$ and $\mathrm{F}$ rats -8.3 and $9.7 \mathrm{ng} \cdot \mathrm{g}^{-1}$ (fresh weight), respectively. The digestibility of Cry $1 \mathrm{Ab}$ protein was estimated to be $80.3 \%$ for $\mathrm{F}$ and $83.7 \%$ for $\mathrm{M}$ rats. The Cry1 $\mathrm{Ab}$ protein was detected in the contents of the stomach, caecum and
Table 4. Detection of recombinant DNA fragments (cry1Ab, nptll, nos) in rat gastrointestinal tract (GIT) contents and tissues and other organs using polymerase chain reaction (PCR)

\begin{tabular}{|c|c|c|c|c|c|c|c|c|}
\hline \multirow{2}{*}{ Sample } & \multicolumn{8}{|c|}{ Animal groups } \\
\hline & $\overline{M-D T}$ & F-DT & M-LT & F-LT & M-DN & F-DN & M-LN & F-LN \\
\hline \multicolumn{9}{|c|}{ GIT tissues } \\
\hline stomach & & - & - & - & - & - & - & - \\
\hline $\begin{array}{l}\text { duode- } \\
\text { num }\end{array}$ & - & - & - & - & - & - & - & - \\
\hline jejunum & - & - & - & - & - & - & - & - \\
\hline ileum & - & - & - & - & - & - & - & - \\
\hline caecum & - & - & - & - & - & - & - & - \\
\hline rectum & - & - & - & - & - & - & - & - \\
\hline liver & - & - & - & - & - & - & - & - \\
\hline spleen & - & - & - & - & - & - & - & - \\
\hline \multicolumn{9}{|c|}{ GIT contents } \\
\hline $\begin{array}{l}\text { stomach } \\
\text { contents }\end{array}$ & - & $\begin{array}{l}+n p t l l \\
+n o s\end{array}$ & ' +nptll & + nos & - & - & - & - \\
\hline $\begin{array}{l}\text { caecum } \\
\text { contents }\end{array}$ & $+n p t l l$ & - & +nos & +nos & - & - & - & - \\
\hline $\begin{array}{l}\text { rectum } \\
\text { contents }\end{array}$ & - & $\begin{array}{l}+ \text { +nptll } \\
+ \text { nos }\end{array}$ & +nos & - & - & - & - & - \\
\hline \multicolumn{9}{|c|}{ Other tissues } \\
\hline blood & - & - & - & - & - & - & - & - \\
\hline brain & - & - & - & - & - & - & - & - \\
\hline heart & - & - & - & - & - & - & - & - \\
\hline lung & - & - & - & - & - & - & - & - \\
\hline kidney & - & - & - & - & - & - & - & - \\
\hline testes & - & - & - & - & - & - & - & - \\
\hline
\end{tabular}

$\mathrm{DN}$ - dark-treated non-transgenic potato, LN - light-treated non-transgenic potato, DT - dark-treated transgenic potato, LT - light-treated transgenic potato, $\mathrm{F}$ - female rats, $\mathrm{M}$ - male rats

rectum (Table 5). None of the GIT contents of the control rats showed a positive reaction for Cryl Ab. The Cry1 Ab protein was not detected neither blood, spleen, brain, duodenum, ileum, jejunum, heart, stomach, liver, testes nor in kidney and lung samples (data not shown).

\section{Detection of NPTII protein}

With the use of ELISA kit the NPTII protein was detected in all GIT contents of rats fed LT and DT potatoes (Table 5). There were no significant differences between LT and DT potatoes for NPTII in the three sections of the GIT tested. The amounts of NPTII protein in diets containing LT and DT potato were 55.15 and $53.97 \mathrm{ng} \cdot \mathrm{g}^{-1}$ (fresh weight), respectively, and the rectal contents of $\mathrm{M}$ and $\mathrm{F}$ rats were between 8.62 and $12.8 \mathrm{ng} \cdot \mathrm{g}^{-1}$ (fresh weight). Based on NPTII content, the digestibility of the protein was from 76.8 to $84.36 \%$ in rats fed transgenic potato. The GIT contents of rats fed nontransgenic potato and all other tissues were negative for NPTII protein. 


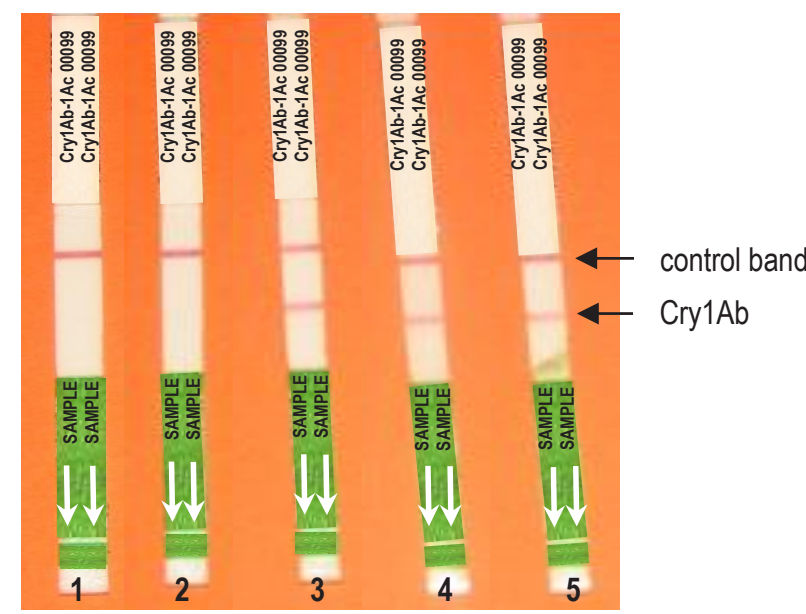

Figure 5. Immunochromatographic strip assay for detection of Cry1 Ab protein in the diets containing: (1) non-transgenic potato (N), (2) darktreated transgenic (DT) potato and (3) light-treated transgenic (LT) potato; and in the gastrointestinal tract contents of rats fed experimental diets: (4) stomach contents of rats fed LT diet and (5) caecum contents of rat fed LT diet

The control band confirms the correct function of the immune-strips; the $\mathrm{Cry} 1 \mathrm{Ab}$ band shows the presence of Cry1 $\mathrm{Ab}$ protein

Table 5. Cry1Ab and NPTII proteins concentration in the diets containing transgenic potatoes and in the gastrointestinal tract (GIT) segments contents of rats fed these diets

\begin{tabular}{|c|c|c|c|}
\hline \multirow{2}{*}{ Sample } & \multirow{2}{*}{$\begin{array}{l}\text { Diet/Animal } \\
\text { group }\end{array}$} & \multirow{2}{*}{$\frac{\text { Cry1Ab }}{\mathrm{ng} \cdot \mathrm{g}^{-1}}$} & \multirow[t]{2}{*}{ NPTII } \\
\hline & & & \\
\hline $\begin{array}{l}\text { Diet containing light-treated } \\
\text { transgenic potatoes }\end{array}$ & LT & $49.8 \pm 3.9^{a}$ & $55.15 \pm 2.4^{a}$ \\
\hline $\begin{array}{l}\text { Diet containing dark-treated } \\
\text { transgenic potatoes }\end{array}$ & DT & $0^{d}$ & $53.97 \pm 2.1^{\mathrm{a}}$ \\
\hline \multirow{4}{*}{ Stomach contents } & F-LT & $22.5 \pm 2.4^{b}$ & $31.1 \pm 1.8^{b}$ \\
\hline & M-LT & $18.6 \pm 1.3^{b}$ & $22.25 \pm 1.45^{\mathrm{cd}}$ \\
\hline & F-DT & $0^{\mathrm{d}}$ & $20.35 \pm 1.44^{d}$ \\
\hline & M-DT & $0^{d}$ & $25.6 \pm 1.46^{c}$ \\
\hline \multirow[t]{4}{*}{ Caecum contents } & F-LT & $12.5 \pm 1.26^{c}$ & c $\quad 14.4 \pm 0.91^{\mathrm{ef}}$ \\
\hline & M-LT & $11.5 \pm 1.32^{c}$ & $15.5 \pm 1.1^{\mathrm{e}}$ \\
\hline & F-DT & $0^{d}$ & $13.8 \pm 0.96^{e f}$ \\
\hline & M-DT & $0^{d}$ & $12.8 \pm 1.03^{\mathrm{efg}}$ \\
\hline \multirow[t]{4}{*}{ Rectum contents } & F-LT & $9.1 \pm 1.83^{c}$ & c $\quad 10.1 \pm 0.86^{f g}$ \\
\hline & M-LT & $8.3 \pm 0.64^{c}$ & c $12.8 \pm 0.73^{\mathrm{efg}}$ \\
\hline & F-DT & $0^{d}$ & $8.62 \pm 0.38^{f g}$ \\
\hline & M-DT & $0^{d}$ & $10.8 \pm 1.03^{\text {fg }}$ \\
\hline
\end{tabular}

All samples were determined in duplicate; Data are presented as mean values $\pm S E$; ${ }^{a-g}$ - values with different superscripts within each column are significantly different at $P \leq 0.05 ; \mathrm{F}$ - female rats, $\mathrm{M}$ - male rats

\section{Discussion}

In all raw and unprocessed foods and feeds there are present large numbers of DNA molecules. Food/feed processing often decreases the size of the DNA; therefore, depending on the extent of processing, a defined DNA molecule (e.g., gene) may be of different size in different products (Nielsen and Daffonchio, 2010). Statistically, humans ingest from 0.1 to $1 \mathrm{~g}$ of DNA per day (Doerfler, 2000). Moreover, dead microorganisms and shed intestinal cells continually release DNA into the GIT (Nielsen and Daffonchio, 2010).

Although transgenic crops contain novel sequences of DNA, the transgenes are thought to be chemical equivalent to other genes in the food because they have the same basic components as other DNA segments (El-Sanhoty et al., 2006). Therefore, the risk connected with transgene is mainly focused on the novel genetic composition of the recombinant DNA and not on the overall chemical structures (Nielsen and Daffonchio, 2010).

It is assessed that DNA comprises less than $0.02 \%$ of the total dry matter in the food (Watson and Thompson, 1988), therefore the quantity of any transgene ingested will be a minor fraction of the total DNA consumed per human per day. Pre-consumption food processing and digestion in the GIT alter the size of a defined gene as less than the length of a single transgene with a complete protein coding sequence. Therefore, introduction of a complete and functional sequence of a transgene to prokaryotic or eukaryotic cell is a rare phenomenon in the GIT. In the present study nos, nptII and crylAb genes were identified in all diets containing transgenic potato tubers using PCR analysis. It was concluded that the potato grinding and heating (for diet preparation) did not cause a significant degradation of DNA (ElSanhoty et al., 2006).

It was also shown that complete sequences (1200 bp) and those decreased in size (400 bp) of the cryl Ab gene were not detected in the GIT contents or in other tissues; however, $400 \mathrm{bp}$ sequence of the nptII gene and $300 \mathrm{bp}$ of the nos promoter and control $c p$ gene were detected in the caecum, stomach and rectal contents of some rats fed transgenic potato. They were not detected in all rat tissue.

It was also indicated that feed-ingested DNA is partially resistant to the mechanical, chemical and enzymatic activities of the rat GIT and does not completely degrade. Therefore, recombinant DNA is processed in rat GIT in the same manner as are endogenous feed-ingested genetic materials.

El-Sanhoty et al. (2006) showed that segments from transgenic potato lines could not be found in tissue samples although the diets were offered in the mash form without degradation of the transgenic potato and chloroplast plant DNA. Broll et al. (2005) detected no plant specific DNA or recombinant DNA in the organ of pigs fed transgenic potato. 
These authors also found chloroplast-specific DNA in the digesta of the duodenum, jejunum, colon and rectum, and reported no evidence for integration transgenes in the host.

The presence of recombinant DNA from transgenic plants in the organs and tissues of animals fed transgenic feed has been previously reported as rare (Chowdhury et al., 2003; Broll et al., 2005; Mazza et al., 2005; Sharma et al., 2006; Swiatkiewicz et al., 2014). Sharma et al. (2006) reported that native plant DNA and the cp4-epsps transgene can be detected in the GIT digesta and in tissues and organs of fish and pigs fed transgenic Roundup-Ready canola meal. It was concluded that there was no evidence to suggest that transgenes would be processed in the gut differently from ingested native feed genetic material (Sharma et al., 2006). Walsh et al. (2011) detected transgenic DNA (crylAb) and protein only in the GIT digesta and not in the tissues (kidney, liver, muscle, heart or blood) of pigs fed Bt MON810 maize.

Grønsberg et al. (2011) reported that the low level of plasmid DNA introduced in feed was transiently detected in organs of young, growing rats; however, there was no indication of increased DNA uptake levels in the GIT of growing rats (Grønsberg et al., 2011). Chowdhury et al. (2003) detected endogenous gene segments of maize (zein, $242 \mathrm{bp}$; invertase, $226 \mathrm{bp}$; rubisco, $1028 \mathrm{bp}$ ) in the GIT contents of pigs fed $\mathrm{Bt}$ and non-transgenic maize. The presence of cryl Ab gene segments (110 bp and $437 \mathrm{bp}$ ) was found in the GIT contents of the pigs fed Bt maize, but not in the control pigs. Also, PCR analysis did not reveal intrinisic maize or $c r y l A b$ gene fragments in the peripheral blood (Chowdhury et al., 2003).

The results of the present study suggest that $c r y$ $1 \mathrm{Ab}$ gene sequences may be degraded into small segments while digested in the GIT; however, the primer pairs for detection of a shorter length $(<400 \mathrm{bp})$ of $c r y l A b$ gene increased the chance of detection of the cry $1 A b$ gene in the GIT contents.

The potential for horizontal transfer of antibiotic-resistant selectable marker genes used to generate transgenic plants into GIT microflora is of a common concern. If so, the distribution of antibiotic resistance in GIT microflora may be at risk. Approximately $31.7 \%$ of all transgenic events approved for commercialization contain $n p t I I$ gene as a selectable marker (Breyer et al., 2014). In the present study the $400 \mathrm{bp}$ sequence of $n p t I I$ gene in the caecum, stomach and rectum contents of rats fed transgenic potato was detected; however, there was no signs of concern about horizontal transfer of nptII gene to GIT microflora.
International regulatory agencies have approved the commercial release of transgenic potato, tomato, canola, maize, chicory, flax, and cotton containing the nptII gene (Breyer et al., 2014). The GMO panel of the European Food Safety Authority (EFSA) has accepted marketing of GMO potato containing the nptII gene (EFSA, 2007). The EFSA believes that the frequency of gene transfer from plants to bacteria is extremely low (Devos et al., 2014). Basing on many reports (Ramessar et al., 2007; Breyer et al., 2014) EFSA concluded that the presence of antibiotic-resistance marker genes, in particular the nptII gene, in transgenic plants does not bring any disadvantages to human or animal health or to the environment (EFSA, 2007, 2009).

The results of the present study show that Cry $1 \mathrm{Ab}$ protein can be detected in the GIT contents of rats fed LT transgenic potato. The Cry1Ab protein in the DT diets and GIT contents of rat fed DT potato was not detected since dark conditions could not activate the light inducible promoter (PEPC) to the expression of Cry1 Ab protein in the transgenic potato. Proteomic analysis confirmed that the amount of Cry1 $\mathrm{Ab}$ protein in the stomach, caecum and rectum contents was lower than in the uningested transgenic diets (Table 4). It was concluded that Cry $1 \mathrm{Ab}$ protein was partially degraded by passing through the GIT. Positive immunoassay of Cry $1 \mathrm{Ab}$ in GIT suggested that, although ingested protein had mostly degraded, the antigenicity of the Cry $1 \mathrm{Ab}$ was retained in the GIT. The amount of CrylAb in the rectum contents was lower than in the primary GIT sections. Moreover, there was no significant difference between $\mathrm{F}$ and $\mathrm{M}$ rats in digestion of Cry $1 \mathrm{Ab}$ protein. Chowdhury et al. (2003) reported similar results for calves fed Bt11 maize. At least a dozen reports confirmed the safety of Cryl $\mathrm{Ab}$ proteins in mammalian gut epithelial cells because they lack Cry protein receptors (Kuiper et al., 2001).

In the present study the NPTII protein was found in all GIT contents of rats fed transgenic potato, but it was observed that NPTII was digested in $84.6 \%$ while passing through the GIT. There are no reports indicating such adverse effects of either NPTII or the nptII gene on humans, animals or the environment (Breyer et al., 2014; Devos et al., 2014).

In mice, purified NPTII degrades rapidly in simulated gastric and intestinal fluids (Fuchs et al., 1993). Most (if not all) NPTII can be inactivated or degraded by the acidic environment and digestive enzymes in the stomach and small intestine (EFSA, 2004). The EFSA concluded that the therapeutic use of kanamycin would not be compromised and that allergic responses would be unlikely (EFSA, 2004). 


\section{Conclusions}

Endogenous and recombinant DNA exhibit similar stability and persistence in the gastrointestinal tract (GIT). Although ingested native and recombinant DNA and protein were not totally degraded in the GIT, it is believed that there is no concern for animal and human consumption of recombinant $c r y l A b$ and $n p t I I$ genes and their products.

\section{Acknowledgement}

The research was supported by Agricultural Biotechnology Research Institute of Iran (Project No. 89002-8805-05-05-12).

\section{References}

Breyer D., Kopertekh L., Reheul D., 2014. Alternatives to antibiotic resistance marker genes for in vitro selection of genetically modified plants - scientific developments, current use, operational access and biosafety considerations. Crit. Rev. Plant Sci. 33, 286-330, https://doi.org/10.1080/07352689.2 013.870422

Broll B., Zagon J., Butschke A., Leffke A., Spiegelberg A., Böhme H., Flachowsky G., 2005. The fate of DNA of transgenic inulin synthesizing potatoes in pigs. J. Anim. Feed. Sci. 14, Suppl. 1, 337-340, https://doi.org/10.22358/jafs/70573/2005

Buzoianu S.G., Walsh M.C., Rea M.C. et al., 2012. Effects of feeding $\mathrm{Bt}$ maize to sows during gestation and lactation on maternal and offspring immunity and fate of transgenic material. PLoS ONE 7, e47851, https://doi.org/10.1371/journal. pone. 0047851

Chowdhury E.H., Kuribara H., Hino A., Sultana P., Mikami O., Shimada N., Guruge K.S., Saito M., Nakajima Y., 2003. Detection of corn intrinsic and recombinant DNA fragments and Cry1 $\mathrm{Ab}$ protein in the gastrointestinal contents of pigs fed genetically modified corn Bt11. J. Anim. Sci. 81, 2546-2551, https://doi. org/10.2527/2003.81102546x

Devos Y., Aguilera J., Diveki Z., Gomes A., Liu Y., Paoletti C., du Jardin P., Herman J., Perry J.N., Waigmann E., 2014. EFSA's scientific activities and achievements on the risk assessment of genetically modified organisms (GMOs) during its first decade of existence: looking back and ahead. Transgenic Res., 23, 1-25, https://doi.org/10.1007/s11248-013-9741-4

Doerfler W., 2000. Foreign DNA in Mammalian Systems. WileyVCH Verlag $\mathrm{GmbH}$, Wennheim (Germany), https://doi. org/10.1002/9783527613465

Dona A., Arvanitoyannis I.S., 2009. Health risks of genetically modified foods. Crit. Rev. Food Sci. Nutr. 49, 164-175, https://doi. org/10.1080/10408390701855993

Duggan P.S., Chambers P.A., Heritage J., Forbes J.M., 2000. Survival of free DNA encoding antibiotic resistance from transgenic maize and the transformation activity of DNA in ovine saliva, ovine rumen fluid and silage effluent. FEMS Microbiol. Lett. 191, 71-77, https://doi.org/10.1111/j.1574-6968.2000. tb09321.x

Duggan P.S., Chambers P.A., Heritage J., Forbes J.M., 2003. Fate of genetically modified maize DNA in the oral cavity and rumen of sheep. Br. J. Nut. 89, 159-166, https://doi.org/10.1079/ BJN2002764
El-Sanhoty R.M.E.S.S., El-Maged A.D.A., Ramadan M.F., 2006. Safety assessment of genetically modified potato Spunta: degradation of DNA in gastrointestinal tract and carryover to rat organs. J. Food Biochem. 30, 556-578, https://doi. org/10.1111/j.1745-4514.2006.00082.x

European Food Safety Authority (EFSA), 2004. Opinion of the Scientific Panel on Genetically Modified Organisms on the use of antibiotic resistance genes as marker genes in genetically modified plants. EFSA J. 2, 48, https://doi.org/10.2903/j. efsa.2004.48

European Food Safety Authority (EFSA), 2007. Statement on the safe use of the nptll antibiotic resistance marker gene in genetically modified plants by the Scientific Panel on Genetically Modified Organisms. EFSA J. 5, 742, https://doi.org/10.2903/j. efsa.2007.742

European Food Safety Authority (EFSA), 2009. Consolidated presentation of the joint Scientific Opinion of the GMO and BIOHAZ Panels on the "Use of Antibiotic Resistance Genes as Marker Genes in Genetically Modified Plants" and the Scientific Opinion of the GMO Panel on "Consequences of the Opinion on the Use of Antibiotic Resistance Genes as Marker Genes in Genetically Modified Plants on Previous EFSA Assessments of Individual GM Plants". EFSA J. 7, 1108, https://doi. org/10.2903/j.efsa.2009.1108

Fuchs R.L., Ream J.E., Hammond B.G., Naylor M.W., Leimgruber R.M., Berberich S.A., 1993. Safety assessment of the neomycin phosphotransferase II (NPTII) protein. Nat. Biotechnol. 11, 1543-1547, https://doi.org/10.1038/nbt1293-1543

Gallori E., Bazzicalupo M., Dal Canto L., Fani R., Nannipieri P., Vettori C., Stotozky G., 1994. Transformation of Bacillus subtilis by DNA bound on clay in non-sterile soil. FEMS Microbiol. Ecol. 15, 119-126, https://doi.org/10.1111/j.1574-6941.1994. tb00236.x

Ghasimi Hagh Z., Rahnama H., Panahandeh J., Rouz B.B.K., Jafari K.M.A., Mahna N., 2009. Green-tissue-specific, $C_{4}$ PEPC-promoter-driven expression of Cry1Ab makes transgenic potato plants resistant to tuber moth (Phthorimaea operculella, Zeller). Plant Cell Rep. 28, 1869-1879, https:// doi.org/10.1007/s00299-009-0790-3

Grønsberg I.M., Nordgård L., Fenton K., Hegge B., Nielsen K.M., Bardocz S., Pusztai A., Traavik T., 2011. Uptake and organ distribution of feed introduced plasmid DNA in growing or pregnant rats. Food Nutr. Sci. 2, 377-386, https://doi. org/10.4236/fns.2011.24053

He X.Y., Tang M.Z., Luo Y.B., Li X., Cao S.S., Yu J.J., Delaney B., Huang K.L., 2009. A 90-day toxicology study of transgenic lysine-rich maize grain (Y642) in Sprague-Dawley rats. Food Chem. Toxicol. 47, 425-432, https://doi.org/10.1016/j. fct.2008.11.032

Koch M.S., Ward J.M., Levine S.L., Baum J.A., Vicini J.L., Hammond B.G., 2015. The food and environmental safety of Bt crops. Front. Plant Sci. 6, 283, https://doi.org/10.3389/ fpls.2015.00283

Kosieradzka I., Vasko V., Szwacka M., Przybysz A., Fiedorowicz Sz., 2010. Evaluation of the possibility of horizontal gene transfer and accumulation of transgenic DNA from the diet in the bodies of rats. J. Anim. Feed Sci. 19, 307-315, https://doi. org/10.22358/jafs/66294/2010

Kuiper H.A., Kleter G.A., Noteborn H.P.J.M., Kok E.J., 2001. Assessment of the food safety issues related to genetically modified foods. Plant J. 27, 503-528, https://doi.org/10.1046/j.1365313X.2001.01119.x 
Mazza R., Soave M., Morlacchini M., Piva G., Marocco A., 2005. Assessing the transfer of genetically modified DNA from feed to animal tissues. Transgenic Res. 14, 775-784, https://doi. org/10.1007/s11248-005-0009-5

National Research Council (NRC), 1995. Nutrient Requirements of Laboratory Animals. $4^{\text {th }}$ Revised Edition. The National Academies Press. Washington, DC (USA), pp. 11-79, https://doi. org/10.17226/4758

Nielsen K.M., Bones A.M., Smalla K., van Elsas J.D., 1998. Horizontal gene transfer from transgenic plants to terrestrial bacteria a rare event? FEMS Microbiol. Rev. 22, 79-103, https://doi. org/10.1111/j.1574-6976.1998.tb00362.x

Nielsen K.M., Daffonchio D., 2010. Unintended Horizontal Transfer of Recombinant DNA. TWN Biotechnology and Biosafety Series No. 13. TWN. Penang (Malaysia)

Ramessar K., Peremarti A., Gómez-Galera S., Naqvi S., Moralejo M., Muñoz P., Capell T., Christou P., 2007. Biosafety and risk assessment framework for selectable marker genes in transgenic crop plants: a case of the science not supporting the politics. Transgenic Res. 16, 261-280, https://doi.org/10.1007/ s11248-007-9083-1

Reuter T., Aulrich K., 2003. Investigations on genetically modified maize (Bt-maize) in pig nutrition: fate of feed-ingested foreign DNA in pig bodies. Eur. Food Res. Technol. 216, 185-192, https://doi.org/10.1007/s00217-002-0642-7

Sharma R., Damgaard D., Alexander T.W., Dugan M.E.R., Aalhus J.L., Stanford K., McAllister T.A., 2006. Detection of transgenic and endogenous plant DNA in digesta and tissues of sheep and pigs fed Roundup Ready canola meal. J. Agric. Food Chem. 54, 1699-1709, https://doi.org/10.1021/jf052459o

Snell C., Bernheim A., Bergé J.-B., Kuntz M., Pascal G., Paris A., Ricroch A.E., 2012. Assessment of the health impact of GM plant diets in long-term and multigenerational animal feeding trials: A literature review. Food Chem. Toxicol. 50, 1134-1148, https://doi.org/10.1016/j.fct.2011.11.048
Swiatkiewicz S., Swiatkiewicz M., Arczewska-Wlosek A., Jozefiak D., 2014. Genetically modified feeds and their effect on the metabolic parameters of food-producing animals: A review of recent studies. Anim. Feed Sci. Technol. 198, 1-19, https://doi. org/10.1016/j.anifeedsci.2014.09.009

Świątkiewicz S., Koreleski J., Arczewska-Włosek A., Świątkiewicz M., Twardowska M., Markowski J., Mazur M., Sieradzki Z., Kwiatek K., 2011. Detection of transgenic DNA from Bt maize and herbicide tolerant soybean meal in tissues, eggs and contents of segments of digestive tract in laying hens fed diets containing genetically modified plants. Ann. Anim. Sci. 11, 413-424

Tudisco R., Lombardi P., Bovera F., d'Angelo D., Cutrignelli M.I., Mastellone V., Terzi V., Avallone L., Infascelli F., 2006. Genetically modified soya bean in rabbit feeding: detection of DNA fragments and evaluation of metabolic effects by enzymatic analysis. Anim. Sci. 82, 193-199, https://doi.org/10.1079/ ASC200530

Walsh M.C., Buzoianu S.G., Gardiner G.E., Rea M.C., Gelencsér E., Jánosi A., Epstein M.M., Ross R.P., Lawlor P.G., 2011. Fate of transgenic DNA from orally administered Bt MON810 maize and effects on immune response and growth in pigs. PLoS ONE 6, e27177, https://doi.org/10.1371/journal. pone.0027177

Watson J.C., Thompson W.F., 1988. Purification and restriction endonuclease analysis of plant nuclear DNA. In: A. Weissbach, $\mathrm{H}$. Weissbach (Editors). Methods for Plant Molecular Biology. Academic Press, San Diego, CA (USA), https://doi. org/10.1016/B978-0-12-743655-5.50009-9 